\title{
The European and Russian Far Right as Political Actors: Comparative Approach
}

\author{
Ivanova Ekaterina ${ }^{1}$, Kinyakin Andrey ${ }^{1} \&$ Stepanov Sergey ${ }^{1}$ \\ ${ }^{1}$ RUDN University, Russia \\ Correspondence: Stepanov Sergey, RUDN University, Russia. E-mail: sstep1966@mail.ru
}

Received: March 5, 2019

Accepted: April 25, 2019 Online Published: May 30, 2019

doi:10.5539/jpl.v12n2p86

URL: https://doi.org/10.5539/jpl.v12n2p86

The article is prepared within the framework of Erasmus + Jean Monnet Module "Transformation of Social and Political Values: the EU Practice" (575361-EPP-1-2016-1-RU-EPPJMO-MODULE, Erasmus + Jean Monnet Actions) (2016-2019)

\begin{abstract}
The article is devoted to the comparative analysis of the far right (nationalist) as political actors in Russia and in Europe. Whereas the European far-right movements over the last years managed to achieve significant success turning into influential political forces as a result of surging popular support, in Russia the far-right organizations failed to become the fully-fledged political actors. This looks particularly surprising, given the historically deep-rooted nationalist tradition, which stems from the times Russian Empire. Before the 1917 revolution, the so-called «Black Hundred» was one of the major far-right organizations, exploiting nationalistic and anti-Semitic rhetoric, which had representation in the Russian parliament - The State Duma. During the most Soviet period all the far-right movements in Russia were suppressed, re-emerging in the late 1980s as rather vocal political force. But currently the majority of them are marginal groups, partly due to the harsh party regulation, partly due to the fact, that despite state-sponsored nationalism the position of Russian far right does not stand in-line with the position of Russian authorities, trying to suppress the Russian nationalists. This is sharply contrasting to the situation with the far right in Europe, which are more well-established and institutionalized as political actors, using conventional forms of political activity. However, despite development gap in comparison with the European counterparts, the Russian far right have obvious potential as political actors, which can be realized under certain circumstances, enabling them to play more significant in the political system of Russia.
\end{abstract}

Keywords: the far-right, nationalism, the european nationalists, Russian nationalists, "Black hundred", "Union of Russian people", "Russian National Unity", Russian marches

\section{Introduction}

During the last years, the political landscape of Europe has significantly changed. Far-right and nationalist parties have grown from marginal groups to important political actors in many European countries, becoming significant competitors to the traditional - liberal, socialist and centrist parties. The list of the European far-right is very long: "the Alternative for Germany" (AfG), "British National Party" (BNP), "Danish People's Party" (DF), "the Golden Dawn" (People's Association) in Greece, "Jobbik" (Movement for a Better Hungary), "the Lega Nord" (Northern League) in Italy, "the National Front" (FN) in France, "the Party of Freedom" (PVV) in Netherlands, the "Fremskrittspartiet" (Progress Party) in Norway, "the Sweden Democrats" (SD) in Sweden, "the True Finns" (PS) in Finland, the "Vlaams Belang" (Flemish Interest) in Belgium and others.

Despite some differences in institutional and functional aspects, these parties and movements have lots in common. Firsts of all they share principles, based on anti-globalism, anti-immigration, euroscepticism and nationalism. Whereas the Western European far-right parties focus mainly on immigration and migrants, their Eastern European "colleagues" target target ethnic minorities - Roma, Jews and other ethnic minority groups. Given the surge of political risks (lack of good governance), emergence of social problems (migration crisis) and economic uncertainty, many European voters have turned to far-right and nationalist ideas, enabling surge of the popular support of the far right.

To make it clear none of the European nationalist and far-right parties has so far won the national elections in 
their own country. But many have already achieved significant success, by getting $20-30 \%$ of votes. This progress of the European far right has become especially noticeable in the last two years.

Marine Le Pen, the leader of "the National Front" (now "National Rally"), finished second in the first round of the presidential election 2017 in France and she managed to obtain 33.9\% of votes in the second round. Her Dutch associate and colleague Geert Wilders, the leader of "the Party of Freedom", also showed a good result within the general elections in 2017 in Netherlands, capturing 20 seats in the Dutch Parliament -States General and managing to form the second-largest faction. One of the major results German federal elections in 2017 became the breakthrough of the far-right party "Alternative for Germany", which received 94 seats $(12.9 \%)$ in the Bundestag. In 2018 the Sweden Democrats became the third-largest party in the Riksdag - Swedish parliament as the result of the Swedish general elections. During the Italian general election, which were held in March 2018, the far-right Nord League came third, forming the not only the third-largest faction in the Parliament, but also managed to get into the government, forging the coalition with the political opponents.

At the moment the far-right parties gain support not only on the national, but also on the supranational level. In May 2019 the European parliament elections are to take place. And according the polls, the extreme far-right can capture up to the third of the all seats (Foundation Robert Shuman, 2019). If it happens the far-right can become one of the major political forces within the European Union, which not only opens a new chapter in the European politics, but also sets a precedent, creating the far-right pattern for the nationalists all over the world. No exception are Russian nationalists, who not only having much in common with the European counterparts but who have certain potential as political forces.

\section{Theoretical and Methodical Framework}

The European far right is not a new object for research consideration. Given their role as "immanent evil" in the democratic political system as well as function of "marginal opponents" for the traditional political parties, there is rather huge bulk of researches, devoted to the different aspects of activity of the far right. However, many scholars tried to concentrate mainly on the ideological aspects (Ignazi, 1992; Art, 2011; Della Porta 1995, 2013).

Whereas the more interesting issue is, the specifics of activity the European far right movements within certain political systems as political actors. Such a country analysis, which gives insights to the peculiarities of the development of the far-right movements in Europe turns out to be very fruitful. Especially given the enhancing trend of increase of popular support of the populists and right-wing politicians, which, from the perspective of some scholars is a long-lasting (Mudde, 2016).

In this respect it is extremely important not only to analyze the far-right movements in the Western European countries, such as Germany (Wagemann, 2005; Zimmermann, 2013, Heitmayer, 2003), the Netherlands (Braun, 2003) and Scandinavian states (Bjørgo, 1997), but also in the Eastern Europe, which has certain potential for the far right ideology (Mickenberg, 2002; Mudde, 2005).

In this sense the analysis of the Russian nationalist organizations is not only relevant but can provide additional insights into the specifics of the East European far right. The ideological and historical roots of Russian nationalism are presented in detail in the writings of the outstanding Russian thinker Ivan Ilyin (Ilyin, 2007).

The modern nationalist movement in Russia has a short history, but it has already attracted the attention of many researchers, who try to focus on different aspects of Russian far-right movements (Dunlop, 1985; Solovey, 2009; Verkhovsky, 2009). The rather new line of analysis of the Russian far right is the consideration of the links between European and Russian nationalists. This issue, which is studied in specific researches (Shekhovtsov, 2017; Laruelle, 2018) is rather important for this paper, which envisages comparative analysis.

The research methodology, elaborated for this paper is based on sets of social sciences methods - comparative analysis, discourse analysis, structural and functional analysis, sociological analysis, and extrapolation.

The selected methods turn out to be helpful in reaching the research goals and to prove the main hypothesis.

The authors pursued comparative analysis as a central mode of investigation, framing the comparative model on the specially elaborated sets of criteria and provided empirical data on the European as well as Russian nationalist organizations.

\section{The Hypothesis and Goals of the Research}

Despite a vast research base, covering the issues of the far right it should be admitted, that there is the lack of researches, dealing with the issue of development of the contemporary Russian nationalism as well as comparative analysis of the far right in Russia and in Europe.

Whereas the latter turns out to be important in assessing the global trends in development of the far-right 
movements as international political actors.

And this research aims to fill this gap. The authors consider it necessary to formulate the following debatable questions concerning the comparative analysis of nationalists in Europe and Russia:

- Do the European and Russian far right significantly differ from each other?

- What are the reasons for popular support of European and Russian far right?

- What are the forms and tools of political activity of European and Russian far right?

- Do the European and Russian far right have perspective as political actors?

By giving the answers on these questions it is worth formulating the following research hypothesis: despite significant differences in institutional, organizational and functional aspects due to distinctions in political traditions and current political environment the far right in Russia and in Europe demonstrate some similarities not only in ideological (nationalist, xenophobic) sense, but also in practical aspects (activities). All this pave the way for stepping up cooperation between the Russian and European far right. Especially if the current trends of worsening/deterioration of the economic and social situation (welfare state dismantling) as a result of the lack of good governance on the national and supranational levels and the increase of popular support of far-right ideology/movements all over the world will be gaining momentum.

\section{The Far-Right Movements in Europe: Major Insights}

The phenomenon of the European far right (in literature and media are also widespread notions "ultra-right," "right-wing radicals" and "right-wing") is not only strongly connected with the deep-rooted xenophobic tradition in many European societies as well as is the specifics of social, economic and political development in Europe but also has evident ideological background, stemming from the nationalist ideology.

Its emergence can be tracked back to the French revolution in 1789, which paved the way to the nation-state building all across Europe.

However, even before that there were some manifestations of nationalism among ethnic minorities within different European empires. ${ }^{1}$

The huge boost for emergence of nationalist movements in Europe was made by the Napoleonic wars, which distributed the ideas of liberalism (the triad "liberty, equality and brotherhood") and national self-determinism in Europe (Betz, 1994).

The Congress in Vienna in 1815, which drew a line under the "French revolutionary turmoil" and led to restauration of many European monarchies, became the trigger of so called "romantic nationalism" - emergence of national liberation movements in Europe.

Especially it was strong in the Southern Europe, which for the centuries was suffering under the rule of the Ottoman Empire and where nationalism was not only the matter of nation-state building, but also had evident identical (ethnic, religious) dimension. The rise of national liberation movements in many Southern European countries, stipulated the outburst of independence wars with the strong nationalist component, resulting the obtainment of statehood and establishing the nation-states like in cases of Greece (1829) and Serbia (1830).

Besides the Southern Europe, nationalism became widespread in other regions of Europe with the Swedish-Norwegian war (1814), Belgian revolution (1830) and series of revolts in Poland (1830-1831).

The rising revolutionary activity in different parts of Europe erupted in 1848 with the revolutions in most of the European nations, resulting the emergence of nationalist (liberation) movements as poor-organized but ideologically "ripe" actors, enjoying the massive support within national/ethnic groups. The most active the nationalist movements were in the multi-national European empires, such as Austro-Hungary, where the national minorities were not openly suppressed but partly deprived of their national identity because of pursued state-sponsored integration policy (Germanization) $)^{2}$ (Kitschelt, 1997).

The aspiration for nation-state building was the dominant motive of the European nationalism within second half of the 19th - beginning of 20th century, contributing to formation of dozens of centralized nation-states Romania (1859), Italy (1861), Germany (1871), Hungary (1867), Norway (1905), Bulgaria (1908), Albania

\footnotetext{
${ }^{1}$ For example, the first Polish nationalist groupings (proto-organizations) emerged shortly after the accession of part of Poland to the Russian Empire as a result of the first partition of Poland between Russia, Prussia and Austria-Hungary in 1772.

${ }^{2}$ In this sense very remarkable can be the example of the Czech, whose language (čeština) was almost lost within the period of being part of the Austro-Hungarian Empire due to the dominance of German language and revived only in the $19^{\text {th }}$ century.
} 
(1912).

This period is also remarkable by formation of nationalism as full-fledged ideology, which cornerstone became national identity.

Being always the essential element of statehood, within the nationalist ideology it was converted into the tool, which not only differentiates "compatriots" from "aliens", but also promotes superiority of certain nations.

This paved the way to emergence of the new type of nationalist movements, which were no more bearers of idea of national liberation, but adherents of establishment of the of national superiority. These organizations became widespread in Europe in end of 19th - beginning of 20th century and were largely promoters of state-sponsored nationalism based on the principal of national identity and despite their status of marginal and even more extremist (or far right) forces were rather popular playing a significant role in the national politics.

The surge of nationalism in Europe in the beginning of 20th century became one of the reason of many military conflicts and gravely contributed to the outburst of the WWI, which to some extent finalized the process of emergence of nation-states with the dissolution of multinational state formations such as Austro-Hungary, Russian and Ottoman Empire and emergence of the new nations, some barely having the tradition of statehood (for instance, Latvia or Estonia).

The end of the WWI had significant impact on the development of European nationalism, given the fact that defeated nations had to cope with economic hardships and deterioration of the social sphere, what gave fertile soil for many far right movements.

The most remarkable is the example of Germany, which within interwar period had to witness the surge of nationalism given the poor economic and social conditions as well as prevailing revanchist sentiments in the society. All this resulted the surge of popular support of extremist forces, which eventually were granted access to power. Moreover, the rise of Nazi party in Germany, which ideology was based on the principles of far right nationalism (not only national identity, but also the xenophobic ideas - ethnic superiority, racial inferiority) showed the new quality of nationalism - institutionalized (on the basis of political parties) and entrenched into political system.

The interwar period turns out to be especially important in the development of the European nationalism. During this time nationalism became not only widespread all across the Europe, reaching the highest point as ideological movement, but also stipulated the emergence and establishment of new ideologies -fascism and Nazism. Adopted as official ideologies by many European states they contributed to making nationalism a mainstream ideology (Kitschelt, 1997).

But more importantly, during interwar period as well as during the period of WWII nationalism got institutionalized on the basis of not only legal framework or organizations (parties), but also different political and social practices (some ominous). This brought the nationalism to the new level of development as not only well-established ideology but also sets of practices.

Nevertheless, the postwar (after the WWII) period had the remarkable impact on nationalism in Europe. The processes of democratization (denazification), which were put underway in many European nations and had the comprehensive character (encompassing all the spheres) resulted the marginalization of nationalism, which was not only proclaimed as dangerous ideology but also ostracized on the political level, practically outlawing the nationalist and far-right organizations all across Europe.

The postwar period contributed to marginalization of the European far right, which were relegated as political actors. It found its practical embodiment not only in ousting of many far right organizations of taking part in elections, but also the diminishment of number of the far-right organizations. At the same time it enabled the further marginalization of the European far right. This processes was stipulated by the active labor migration processes within Europe in the postwar period as well as crumbling of the colonial system, bringing not only lots of people from the once colonies to the once metropoles (for instance, France, Great Britain, Belgium) but also making migration legislation in many European countries (even not having the "colonial background" like Switzerland) more liberalized. The influx of the migrants in Europe in 1950-1970s gave a serious boost to the development of the far right. Despite the status of marginal forces and prevailing liberal and democratic ideology, they enjoined some popular support, exploiting xenophobic and migrant-phobic sentiments, rather widespread within European societies in that period (Minkenberg, 2000).

The development of the European far right in this period disclosed their nativist nature. Many far right movements adopted the nativism ideology, which envisages the principle of homogenous nation-state exclusively members of the native group («the nation») should inhabit states and non-native elements (persons 
and ideas) are fundamentally posing threat to the homogeneous nation-state (Mudde, 2007). Non-native persons could be, for instance, immigrants or people of another race or religion, whereas non-native ideas - religions, ideologies (Albertazzi, McDonnell, 2008).

Besides nativism the period 1970-1980s was also marked by emergence of euroscepticism - the ideological movement, which postulates the non-participation within the European integration processes in order to preserve national sovereignty and identity. The euroscepticism, which initially wasn't the core element of the ideological agenda of the European far right, within years won the significance, becoming one of the most straight-forward ideologies in 2000s (Lubbers, Scheepers, 2007).

The development of the European far right in 1990s was boosted by the collapse of the Soviet Union. It not only stipulated the dissolution of the Soviet bloc, but also contributed to the rise of nationalism within formally Soviet-oriented Central and East European countries (CEEC), where nationalist and far right movements were fiercely suppressed before.

Moreover, the surge of the nationalism (especially ethnic) in some CEECs turned the malevolent aftermaths (for instance, start of the war in Yugoslavia). The reason for the surge of popularity of nationalist and far right movements in Central and Eastern European states was not only deeply embedded nationalist sentiment given the prevalence of nation-states and lack of interculturality but also the deterioration of social and economic standards as a result of the collapse of communist systems, contributing to radicalization of society and rise of popular support of the extremist forces (for instance, in Eastern Germany) (Ivarsflaten, 2008).

Nevertheless, the emerged far right organizations in many CEECs played the minor role in the political system, being mostly extremist groups. This is sharply contrasted with the situation in West Europe, where the far right were more well-established and good-institutionalized forces, adopting the conventional forms of political activity (first of all political campaigning, envisaging partaking in the elections on different levels).

Among the most active Western European far fight organizations are French "National Rally" (Rassemblement national), until 2018 is known as "National Front' (Front National, FN) and "Freedom Party of Austria" (Freiheitliche Partei Österreichs, FPÖ). The FN, which was established in 1972 as nationalist and anti-immigrant movement, managed to get into the European Parliament in 1984, securing 10 seats and in 1986 captured 35 seats in the French parliament - National Assembly (Norris, 2005).

However, the major success came to the National Front in 2002 when the leader of the party Jean-Mary Le Pen managed to get into the second round of the presidential elections in France, being defeated by the incumbent French president Jean Chirac afterwards.

Behind the success of the FN was not only artful exploiting the anti-immigrant and xenophobic rhetoric but also the deft grass roots political campaigning. But more importantly the results of the FN showed the solid public support, which turned out not only stable, but as further developments proved, being susceptible for further growth amid crisis of the good government system in France.

The "Freedom Party of Austria", which emerged in 1952 as a successor of short-lived "Federation of Independents" (VdU), for the long period of time was portraying itself as the "third force" (besides socialists and conservatives) in the Austrian politics, being adherent to the liberal ideology (Heinisch, 2008).

The situation changed, when the chairman of the party in 1986 became charismatic politician Jörg Haider, who started an ideological turn of the party towards right-wing populism, adopting nationalism and xenophobia as the main party ideology. Despite the status of marginal political force within 1990s the FPÖ managed to increase its popular support, getting the success in 1999 , when it obtained the second place with $26,9 \%$ of votes within parliamentary election, getting the green light for entering the government. Since that time the FPÖ, despite the change of leadership (Jörg Haider was succeeded by Heinz-Christian Strache) is one of the major political forces in Austria, constantly forming the ruling coalition.

The cases of the "National Front" and "Freedom Party of Austria", which once were regarded as deviations within European democracy, proved the first wave of the European far right, playing the significant role as political actors not only on the national, but also on the supranational (European) level. ${ }^{3}$

According to different estimations, only within European Union (28 countries) are currently acting from 70 to 120 registered political organizations, which can be classified as right wing or far right.

Moreover, about $40 \%$ of them were created within period 2000-2015, indicating not only the rising activity of

\footnotetext{
${ }^{3}$ For instance, many far-right parties have their members as the MPs within the European Parliament.
} 
the far-right movements, but also surge of the popular support. At the moment it differs from 3,7\% in Cyprus to $26 \%$ in Austria. However, the aggregate figure among all the European far-right organizations is about $12 \%$ (Figure1).

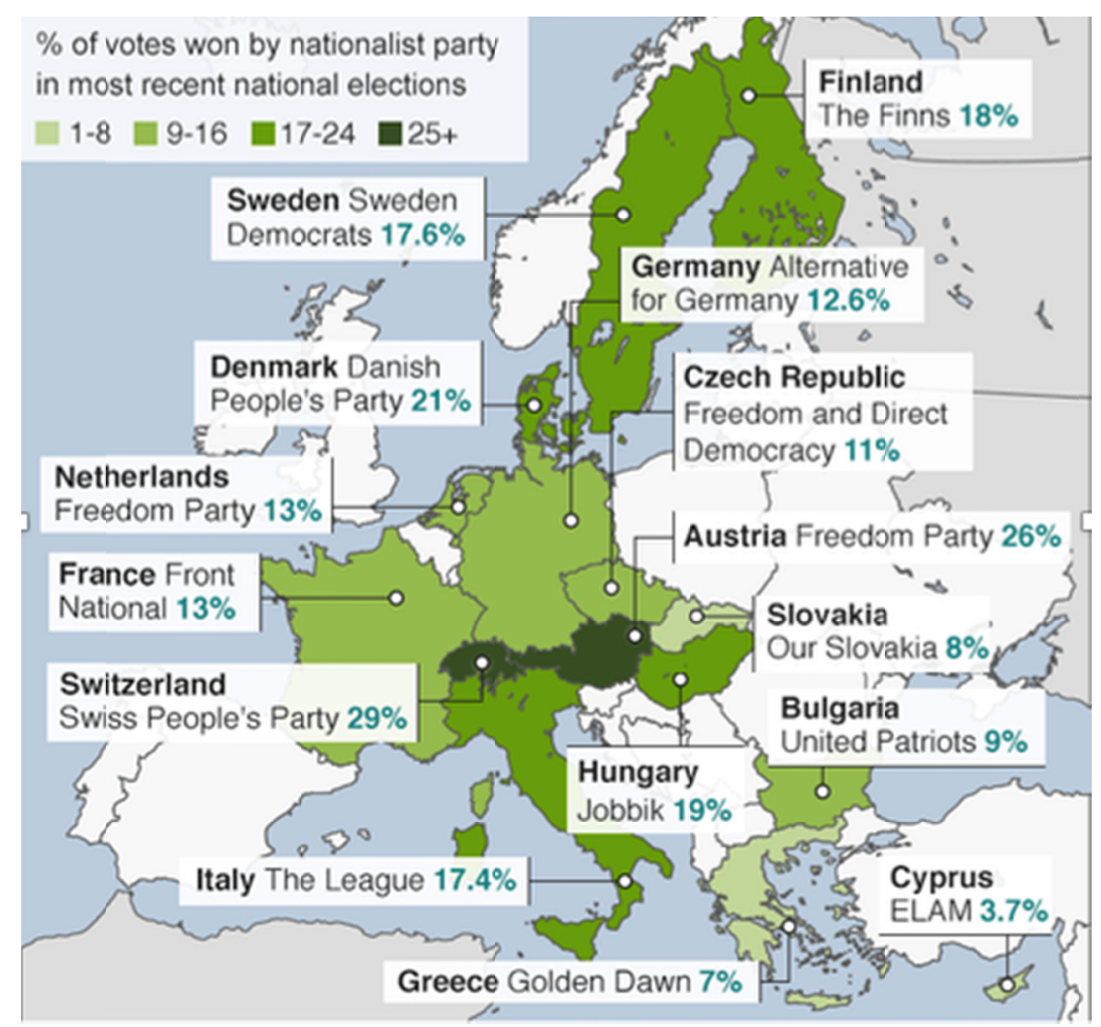

Figure 1. The far right in Europe: popular support (2018)

Source: BBC. URL: https://www.bbc.com/news/world-europe-46422036

The rise of popular support of the far-right organizations can be attributed to two intertwined sustainable trends in social and political life in Europe:

- The growing lack of good-governance, stipulating deterioration of social and economic environment (for instance, the debt crisis, crisis of welfare state);

- The emergence of the new challenges for European countries as the results of the process of globalization (uncontrolled immigration etc.).

All this contributed to the shift in political values from the liberal democracy to right-wing populism, enabling the strengthening of the role of the far-right movements as political actors all across the Europe (Kinyakin, Kazarinova, DeMartino, 2017).

The major connecting point of the European far right is the ideological framework, which comprises several components:

- Nationalism (nativism, ethnicism as well as anti-globalism and denial of multiculturalism);

- Tradionalism (protection of identity, traditional cultural, moral, family and religious values);

- Anti-immigrant sentiment;

- Populism;

- Euroscepticism;

- Authoritarianism.

Nationalism is the core ideological element of the European far right as well as far-right organizations all over the world. All the far-right organizations are proponents of priority of national identity construed as backbone of the nation, being jeopardized by alien influence (ethnic of religious minorities, migrants). The main goal of the far-right organizations as natural-born nationalists is to protect the national identity and nation as a whole. 
In some cases, this nationalism is even combined with secessionism and separatism. For instance, the "Northern League" (Lega Nord) in Italy once advocated the idea of secession of the Northern Italy and formation of the new state - "Padania". The Belgium "Flemish Interest" (Vlaams Belang) maintained as the core element of program the secession of Flanders from Belgium.

On the other hand, many far-right organizations push forward the idea of unification on the linguistic and cultural principles, beyond state borders and thus opposing separatism. For instance, the"Freedom Party of Austria" has long denied the existence of the Austrian nation. Party program of the post-war period comprised the thesis of pan-Germanism. However, later on the party abandoned traditional Greater Germany ideas and change its ideology from pan-Germanism to Austrian patriotism (Heinisch, 2008).

Hungarian right-wing party "Jobbik" is a strong adherent of so-called Pan-Turanism, asserting that Hungarians originate from the Ural-Altaic race. It enabled the political force among other things to established cooperation ties with many Turanian nations, even with the Turkish President Recep Tayyip Erdogan.

Being the proponents of the nationalism the European far right adhere to the xenophobic rhetoric, confronting the accusations of bring the racists. In fact, there are grounds for such allegations. For instance, the predecessor of the "Flemish Interest" - "Flemish Block" in 2004 was charged by the Belgium's Court of Cassation with spreading the racist ideas. That made the party to change its name. However, despite such a move the members of the Flemish interest stayed loyal to their views.

The Swedish far-right party "Swedish Democrats" originally was a group of white supremacists with the strong ties to "White Aryan Resistance" - militant network, being active in Sweden in the early 1990s. This open the door for accusations of party of promoting racism. Sweden's Prime Minister Stefan Löfven blamed the party as being "neo-fascist" (Löfven, 2014).

This notion is often used in respect of European far right. For example, the Newsweek magazine devoted the special material to the strong performance of the "Alternative for Germany" within parliamentary elections in September 2017 under the headline "In German election, neo-nazi fringe rises" (Delcic, 2017).

In some cases, the accusations of racism and suspicions of neo-Nazi are well-grounded, given the historical background. For instance, the founder and the first leader of the Austrian Freedom Party Anton Reinthaller was former SS-officer, whereas the majority of the party members previously were Nazi functionaries (Heinisch, 2008).

The major line of critics of the European far right as being racist is the strong anti-Semitic sentiments. This is partly due to immanent anti-Zionist character of many far-right organizations, partly to the historical background.

Although the leadership of all far right parties strongly rejects allegations of being Nazi and anti-Semitist, lower-ranking party members and activists often use Nazi slogans and greet each other with Nazi salutes.

However, within the last decade, the majority of the far-right parties have taken steps for softening negative image as being anti-Semitic. For instance, Hungarian "Jobbik" changed anti-Zionist position and recognized the right of Israel to exist as a state.

In recent years, the French "National Front" had to face serious alternations and even rebranding, carried out by Marine Le Pen. The reason was the anti-Semitic remarks, made by honorary chairman Jean-Marie Le Pen, who was expelled from the "National Front" in 2015. Geert Wilders, the political ally of Marine Le Pen and the founder of the Dutch right-wing populist "Freedom Party" (Partij voor de Vrijheid), is well known as an ardent fan of Israel. However, at the same time he is a fierce opponent of "Islamization of Europe" as well as immigration.

The anti-Islamic and anti-migrant agendas, promoted by majority of the European far right, can be attributed not only to the prevailing nationalist ideology, but also to the embedded traditionalism. The latter is mainly connected with the strivings to preserve not only national identity, but also the traditional European culture, based on the Christian values and liberal rights, which are hardly correspondent with the norms of Islam, becoming more and more widespread in Europe, due to constant influx of immigrants, who are mostly Muslim.

However, despite of the fact that majority of the European countries are secular, for the far-right organizations religious factor still plays the huge role. But this is mainly dictated by ideological rather than religious views. The founder of Dutch "Freedom Party" Geert Wilders, like his French counterpart Marine Le pen, was raised as Roman Catholic, but left the church in young age and defines himself as an agnostic. However, he promotes Christianity as the core element of European culture and statehood and blames Islam as being aggressive and 
"inhuman", receiving the dubious fame as main European anti-Islamist. He declares: "Islam is not merely a religion, as many people seem to think: Islam is mainly a political ideology" (Geert Wilders Speech, 2010).

Geert Wilders has a lot of like-minded supporters among far right politicians in Europe.

For instance, the Swedish Democrats' chairman Jimmie Akesson compared Islamism with Nazism and modern communism. The Britain "Independence Party" (UKIP) also protested against islamization of Great Britain.

However, not all the far-right politicians are so ardent opponents of Islam. The former leader of the Austrian Freedom Party Jörg Haider had friendly relations with former Libyan leader Muammar Gaddafi, met with late Iraqi president Saddam Hussein, allegedly receiving money for political campaigning from the latter.

Speaking about present days, it should be stated that islamophobia currently dominates in the far-right circles. One striking example is so called "Patriotic Europeans Against the Islamisation of the Occident" (abbreviated PEGIDA). It was founded in October 2014 in German city of Dresden. The foundation of the PEGIDA became a shock for Germany, given the fact, that during the post-war decades any hint of nationalism or racism was strongly condemned by public opinion. But the most striking fact is the huge popular support of PEGIDA, what is not only showing the ongoing alternations in political culture, finding its embodiment in the shift to more radical political values (authoritarianism), but also is strong evidence of the crisis of politics of multiculturalism as well as growing xenophobic sentiments in Germany.

The fertile soil for these sentiments is growing share of non-native population given the migration processes. Presently it differs from country to country, but the average number is about to reach the threshold - $10 \%$ of populace. Given the problems, connected with the integration of immigrants in many European countries as well as economic and social problems, the migration now is one of the major source of xenophobia and popular support of the far-right organizations (Brattberg, Meyerweissflog, 2017).

The latter are aptly exploiting the migrant card, stressing the "alien" background (non-European) as well as risks, connected with the integration of migrants, who are mostly people of different religion and culture (first of all Muslim).

The practical emanation of this rhetoric is, for instance, islamophobia, which is widespread all across Europe. The strongest inslamophobic sentiments are in the countries, which have no "colonial legacy" and try to preserve their status as "pure" nation-states (for instance, Northern, Central and Eastern European countries). ${ }^{4}$

Not surprisingly, that all the European far right are strong and consecutive adherents of limiting the migration in Europe, especially when it handles the illegal migration from the regions, not matching the European culture and values.

In recent years, anti-migrant rhetoric became one of the major tool of winning the popular support by the European far right, given the migration crisis, which was not effectively handled on the supranational (the EU) and national levels, having the strong impact on the welfare state.

More interestingly, that the outburst of the migration crisis contributed to the development of European the far right, namely increase the number of the far-right organizations.

The leader of Danish "People's Party" (DPP) Pia Kjaersgaard declared, that the main reason for founding the DPP is "too many immigrants." The rapid surge of popularity of the "Alternative for Germany" (AfG), which was founded in 2013, is strongly connected with the situation with the migration in the country. Now, AfG is widely regarded as the most active and influential anti-migrant party in Europe.

The migration crisis in Europe of 2015 turns out to be the turning point in development of the European far right as well-established political actors. This can be attributed not only to the surge of the popular support of the far-right organizations, but also to the alternations in interaction with other political forces as well as government In many European counties, the far right became the major critics of the governments, concerning the migration issue. The major point of the critics became the alleged inability to stop the uncontrolled growth of migrants and unwillingness to use the "harsh" but "efficient" tools and methods of solving the migration problem (introduction of new restrictive migration legislation, deportation, readmissions).

But although the European far right are striving to promote theirs ideas and to pursue their goals by using the "high-profile" political tools (electoral activity) in their daily life political activity they opt to use traditional forms and mechanisms, such as mass campaigning (marches, rallies), which contain certain risks of civil disorder.

\footnotetext{
${ }^{4}$ The good illustration is the staunch negative position of the so-called Visegrad group (Poland, Hungary, Czech Republic and Slovakia) towards the idea of introducing migrant quotes, which was promoted by the European Commission amidst the migration crisis in 2015.
} 
In Germany, France, the Netherlands and other countries the marches and rallies, organized by the far-right organizations, often led to conflicts and collisions with political opponents, migrants and police. ${ }^{5}$

The large-scaled character of marches and rallies, which are frequently organized ad hoc as well as growing anti-migrant sentiments in many European countries, became the remarkable evidence of the crisis of multiculturalism policy. The predominant majority of the European far right organizations denied the idea of multiculturalism as destructive to social development, eroding traditional values and cultural archetypes.

Moreover, many far-right movements prefer to present themselves not only as defenders of traditional culture, religion but also promoters of traditional values.

However, in this issue there is so difference between the far-right organizations, connected with the degree of tolerance to sexual minorities. For instance, the UKIP is very conservative on such issues like LGBT rights. Members of the "Golden Dawn" in Greece distributed homophobic pamphlets outside in gay nightclubs. At the same time Beppe Grillo, the founder of Italian "Movement of Five Stars" (M5S), publicly expressed his support for same-sex marriage. Marine Le Pen, once an ardent opponent of LGBT, was forced to soften her conservative views on gay marriage and abortion. The leader of the Dutch Freedom Party leader Geert Wilders openly supports sexual minorities.

Besides nationalism and to some extent traditionalism one of the main "pillars" of the popular support of the European far right is their populism.

Many of promoted by European far-right ideas and propositions (not taking into account the statements) as well as the mechanisms of their implementation are openly populist. Usually far-right politicians offer simple solutions to complex problems, attracting the inexperienced voters in such a way. For instance, Greek "Golden Dawn" party severely condemns the modern political and economic system of Greece and demands introducing the mechanism of direct democracy - to let ordinary people decide about the future of their country without "intrusion of Washington and Berlin". The "Movement of Five Stars" in Italy is widely regarded as populist and anti-establishment, advocating promotion of E-democracy tools (E-voting) and regards Internet as a solution to many social, economic and environmental problems.

The populism, adopted and asserted by the many European far-right organizations attracts not only popular support (especially in countries, facing the economic problems), but also the criticism from the political opponents, blaming the far right for political incompetence and playing up to the radical social sentiments.

One of the relatively new components within ideological framework of the European far right is euroscepticism or the denial of the so-called "European idea". Although it first appeared in 1960s with the active development of European integration, which eventually led to the formation of the European Union as integrationist structure, the real popularity it got in 2000 s, when the European integration process revealed not only profits, but also setbacks for the nations (infringement of sovereignty).

The far-right organizations, which are traditional proponents of the national interests adopted euroscepticism as one of the ideological tools.

One shroud differentiate two types of euroscepticism - "hard" and "soft". "Hard" eurosceptics are the opponents of EU membership in principle. "Soft" euroscepticism supports the functioning of European Union as supranational structure and membership of their states, but exerts criticisms on particular EU policies.

The majority of European far right are the "hard" eurosceptics. Among the consecutive critics of the "European idea" is the French "National Front", which since its creation in 1972 opposes the membership of France within the European Union. The current leader Marine Le Pen promotes the idea of withdrawal from not only the European Union and Eurozone but also from NATO.

One of the huge success of the European far right as eurosceptics became the start of the Brexit (withdrawal of the Great Britain) process, which became the overt evidence of the disintegration of the EU. The process was initiated by the referendum conducted in the 2016, which was strongly supported and promoted by the British far-right organizations (first of all the UKIP).

The results of the Brexit-referendum inspired other European far right to undertake the similar steps. Marine Le Pen and Geert Wilders also exerted their wish to conduct such referendum in France and in the Netherlands respectively and win over the popular support to make so called Fraxit (France withdrawal) and Nexit (the

\footnotetext{
${ }^{5}$ The unorganized far right or so-called "extreme right street" - skinhead groups, Nazis, racists - act more fiercely, using the violent forms and mechanisms.
} 
Netherlands withdrawal).

However, not all the European far right are the adherents of the idea of leaving the EU. For instance, the leaders of the Movement of Five Star", who initially supported the idea of a referendum on the withdrawal Italy from European Union, have eventually abandoned it. Thus, they can be regarded as "soft"eurosceptics. This category includes also the "Alternative for Germany", Danish "People's Party", Hungarian "Jobbik" and others.

It is also worth mentioning, that the European far right are among the most active participants of the European Parliament elections, enjoining the relatively strong popular support and getting the significant representation. The upcoming in May 2019 elections to the European Parliament are not the exclusion. According to the polls, the far-right organizations can get the strong support capturing up to the third of all the seats (751 seats) in the new convocation of the Europarliament (Foundation Robert Shuman, 2019).

Moreover, there are evidences, that in case of the strong performance the far-right organizations can create the join faction, which becomes the one of leading political forces in Europarliament. If it happens, it would be the huge victory of the European far right, letting them definitely establish themselves as not only significant political actors on the national but also on the supranational- European level.

\section{The Far Right in Russia: Major Outlines}

Comparing the positions of the far right in Europe with ones in Russia, we see a significant difference. The far-right organizations in Russia is almost invisible on the political scene: they have no significant influence and do not participate in the elections. This is rather awkward given the fact, that the nationalist tradition in Russia is historically deep-rooted. During the Revolution of 1905 lots of far-right organizations emerged in Russia as a result of revolutionary activity. "The Union of Russian People" (Soyuz russkiogo naroda) and the "Union of the Archangel Michael" (Soiuz Mikhaila Arkhangela) were the largest nationalist parties. All these unions and societies received the collective name of "the Black Hundred" (chernaya sotnya). They united around the state-promoted formula "Orthodoxy, Autocracy, Nationality" (Stepanov, 2013)1. The far-right organizations rejected democratic reforms in Russia. Their leaders and ideologues shared the Slavophiles (slavyanofily) hostility towards the West and Western civilization, which was regarded as a spiritless society based on capital.

"Black Hundred" parties put forward the xenophobic slogan "Russia for the Russians". The manifestos of "the Black Hundred" unions contained the point, envisaging provision civil and economic benefits and privileges for citizens of Russian origin and imposing restrictions on ethnic minorities, living in the Russian Empire. Under Russians, the far right also meant Ukrainians (malorossy) and Belarusians (belorossy). The Poles and the Finns, who were the biggest ethnic minorities, having the autonomous status within the Russian Empire, were viewed as hostile to Russian statehood.

But the greatest threat for the Russian state, from the perspective of "the Black Hundred" organizations, was coming from the Jews. Although anti-Semitic prejudices were widespread in Russia, "the Union of the Russian People" was the only party that openly and defiantly declared itself as anti-Semitism. "The Black Hundred" used conspiracy theories about the plans of the Jews to seize world domination, starting with Russia. The anti-Semitic rhetoric of "the Black-Hundred" newspapers had such resemblances with the successive Nazi propaganda that some scholars argue, that "the Black hundred" movement could be the ideological precursor of German fascism (Rogger, 1964), (Laquer, 1993).

Nationalist and anti-Semitic slogans have attracted many supporters to the ranks of "the Black hundred" organizations given the economic hardships and political turbulence, caused by the revolutionary activities and the defeat in war with Japan (1904-1905). But the organizational aspect was always the "Achilles heel" of the Russian nationalists - amorphous mass membership, total lack of discipline, low activity as institutionalized political actors all this were widespread. The leaders of the far-right alliances swear an oath of loyalty that they defend the Russian monarchy in case of the new revolution. But they could not provide any support for the Emperor when the Russian revolution broke out in February 1917, setting the wave of successive dramatic events (Stepanov, 2018), (Kir'ianov, 2001).

After the Bolsheviks came to power in October 1917 all the far-right movements in Russia were banned. This partly can be attributed to the position of the Bolsheviks, who were the consecutive proponents of internationalism and regarded the "the Black hundred" organizations as arch-rivals, partly due to the fact, that the far right were one of the initiators of the "White movement" (beloe dvizhenie) within the Russian civil war (1918-1922), partly because of dangerous essence of the nationalism in the multiethnic state. Later, during the Soviet period (after 1922) the Communists found a way to combine nationalism with internationalism by promoting the special ideological constructs. But officially during the Soviet period, open manifestations of 
nationalism (not only Russian) were condemned, suppressed and persecuted. To some extent nationalism found its embodiment (but rather weak) only in cultural trends (for instance, literature in native languages) and was not dominant.

But with the start of modernization processes in the Soviet Union known as "Perestroika" nationalists and first of all Russian came out into the open becoming one of the vocal political movements.

One of the first nationalist organizations that emerged in the 1980s was the nationalist and anti-Semitic "The Memory" (Pamyat) society. Its name originated from sponsor - the Soviet Society for the Protection of Historical and Cultural Monuments. Established as an "informal historical, cultural and educational organization" uniting activists-bibliophiles and amateur historians, it became a genuine ideological successor of the pre-revolutionary "the Black Hundred" organizations and was the most active in the 1990s as the far-right and even extremist organization in the1990s.

In 2000s, the national-patriotic front "Pamyat" split into several competing organizations, but it managed to become a human resource source for leaders for many Russian nationalist movements (Mitrohin, 2003). Direct reincarnation of "the Black Hundred" had no success. Although the pre-revolutionary "the Union of Russian People" had been restored, it passed away from the political scene soon not gaining significant popular support (Zaderey, 2012).

Other modern "the Black Hundred" organizations, for example, "Society of Church Banner-Bearers" (Obshestvo khorugvenostsev) were marginalized, given not only malevolent exogenous (harsh state regulation) but also endogenous (poor leadership, inner conflicts) factors. Now these organizations play a minor role as political actors.

Far more active were the Neo-Nazi movements, which emerged in the1990s.It was rather surprising, given the sorrowful legacy of the WWII for the Soviet Union. The most well-established was the "Russian National Unity" (Russkoe nationalnoe edinstvo, RNE) - unregistered political party, which became the proponent of ideology of the Russian extremism. The leader of the RNE Aleksandr Barkashov, the former member of the "Pamyat" society, organized in 1990 the new nationalist organization, which adopted the Nazi Germany symbolic - swastika on red and white background emblem. "The Russian National Unity" openly expressed admiration for German national socialism, although the organization officially denied any support for Nazi ideology. They declared as a major aim of their activity the slogan "Russia for Russians and compatriots" - promoting interest of ethnic Russians and non-Russians who live in Russia and have their national homeland there. "The Russian National Unity" was active not only in Russia, but also in former Soviet republics turned into newly independent states, which had the huge Russian-speaking minorities (Ukraine, Estonia, Latvia and Lithuania). In 1993 RNE took part in the conflict between Russian President Boris Yeltsin and The Supreme Council (Russian parliament within the period 1991-1993), taking the side of the parliament in defending the "Whitehouse" against the President's troops (Stephen, 2001). After Yeltsin's victory the movement worked illegally in the underground. In 1999 after the organization tried to take part in Russian general elections but was expelled (due to the extremist character). Soon afterwards the Moscow headquarter of the party was closed and the organization practically liquidated itself.

Another Nazi-style party was "The National Bolshevik Party"(Nasionalno Bolshevistskaya partia), also known as the "Nazbols", founded by a writer Edward Limonov in 1993. Nazbol's used emblems reminiscent of Nazi emblems although they denied any links to fascism, all forms of antisemitism, xenophobia and racism. Nevertheless, the party was proclaimed as being extremist and was banned by the court decision in 2007.

Nationalist and anti-migrant slogans were also used by legal political parties. "The Liberal-Democratic Party of Russia" (Liberal'no-Demokraticheskaya Partiya Rossii) with its leader Vladimir Zhirinovsky traditionally focuses on nationalist discourse and to some extent can be considered as the far right.

Another bright example of anti-migrant activity was "Motherland-National Patriotic Union" (Rodina). The movement, which was created in 2003 for the upcoming parliamentary elections on the basis of the "Congress of Russian Communities" (Kongress russkih obshchin) - the right-wing political movement, which was very active in the Baltic states, managed to achieve more than $9 \%$ of votes, getting into the State Duma.

Some opponents of the government called the party "the Kremlin project", hinting that the electoral result for newcomer was forged by the Russian authorities. The purpose of "the project" was allegedly to draw nationalist voters away from the extreme National Bolsheviks. The leader of "the Rodina" Dmitriy Rogozin called for patriotism, nationalism, and a greater state role in economy. After the huge success in 2003 the party showed also good results during the successive general elections in Russia $(2007,2011)$. But then it became clear that the 
party was getting out of Kremlin's control, the project was closed after complaints that its electoral publicity contained material inciting national hatred.

A special category of the nationalist organizations in Russia - are anti-migrant movements, which have evident resemblance with the European far right. One of the most active was created in 2002 "the Movement Against Illegal Immigration" (Dvizhenie protiv nelegalnoi immigratsii, DPNI). It was founded as a reaction to ethnic violence between residents of a Moscow's suburb and immigrants from the South Caucasus and Central Asia. The leader of the organization became Aleksandr Belov (Potkin), a former member of ultra-nationalist "Pamyat" organization, declared as the major aim of the organization creating the barriers for the unregistered migrants, who were regarded as a source of ethnic crime. According to Belov`s statements, the DPNI acted solely against illegal migration. But the opponents accused the organization of reviving the slogan «Russia is for Russians», demanded the deportation of Chechen and other Russian ethnic minorities (Kozhevnikova, 2009).

In 2011 DPNI was declared extremist organization by the High Court of Russian Federation and officially banned. The ban had no practical sense, given the fact, that Aleksander Belov as well as his associates Dmitry Dyomushkin and Vladimir Basmanov immediately created the new organization - "the Ethnic-Political Association the "Russians" (Russkie). The Association proclaimed its major goal as to protect the right and interests of the Russian population, both inside Russia and beyond its boundaries. The Association advocated the foundation of a Russian national state and national ("ethnically clean") government as eventual goal.

The emergence of anti-migrant movements proved, that the Russian nationalists are ideologically close to the European far right, putting forward similar demands, often having similar names, but not having similar results. "The Movement Against Illegal Immigration" (DPNI) was founded ten years earlier than "Alternative for Germany" (AfG). But didn't manage to take part in elections on every level and its leaders are now not in parliament but in prison.

One of the reasons (but not the only one) of the situation is severe state regulations resulting repressions on nationalists. To some extent the Kremlin was quite sympathetic to the nationalists and even partially accepted their ideas (in particular, toughing migrant legislation). It is also well known, that some nationalist leaders had hidden connections with high-ranking officials. Moreover, the state provided financial support for the nationalists, letting them to have rallies. It is also not difficult to notice that before 2014 the courts passed rather "soft" sentences to the nationalists, violating the Russian criminal code (namely Art. 282 "enticing national hatred" and "forming extremist community"), even in case of violent actions by neo-Nazi groups.

The situation dramatically changed after 2014. The state began to suppress any display of the nationalism. The first victims became the Russian far right organizations. Russian courts turned into punitive tool sentencing to prison terms the most active public figures of this nationalist segment (the leader of "the Russians" Association Alexander Belov and ex-leader of "the Russian Run" (Russkaia probezhka) in St. Petersburg Maxim Kalinichenko were sentenced for the long terms in custody. Dmitry Dyomushkin (the leader of Slavonic Union (Slavyanskij Soyuz)) was arrested for 15 days for posting a photo image from a comedy movie about Nazi zombies, with a visible swastika on the character's armband. In 2017 he was sentenced for 2,5-year imprisonment for displaying a poster with the inscription "Russian power for Russia".

In 2018 the victim of the state-sponsored campaign became the nationalist organization "Art preparation" (Artpodgotovka), which members were imprisoned en mass. The leader of this organization populist Vyacheslav Maltsev fled abroad, getting the status of political refugee.

It should be stressed, that the Russian nationalists had never access to the media both on federal and regional levels. They were also refused of having their own newspapers or magazines. The only channel for communication for them was internet. But the internet resources, created and run by the Russian far right, are regularly blocked and closed on the ground of enticing national hatred and extremism.

Even for human rights defenders in Russia, who in no way share the views of the far right, admit, that the repression against their opponents creates a contradictory impression. Human Rights Organization SOVA Center for Information and Analysis (SOVA-Center) reported in 2015: «law enforcement agencies successfully reduced the level of racist violence and activities by socially dangerous groups of nationalists. Next, the measures to combat creation and sharing of xenophobic statements too often appear meaningless and disorganized, and, obviously don't achieve their stated goals. Finally, frequent arbitrary actions, as well as excessive or inappropriate restrictions on freedom of speech are not only harmful in and of themselves, but can also discredit the goal of countering radical xenophobia in the public eye» (Yudina, 2015).

According to analysts of the SOVA-center, harsh penalties were associated with the conflict in Ukraine, which 
had been perceived by Russian nationalists in different ways. Some of the them showed solidarity with the Ukrainian nationalists and condemned the annexation of the Crimea and the creation of self-proclaimed republics of Donetsk s and Lugansk.

However, the majority of nationalists supported the so-called "Russian spring" as the first step towards the restoration of the Soviet Union. Many nationalists participated in the hostilities in eastern Ukraine as volunteers. However, the failure of the project of "Russian spring", aiming to bring the Ukrainian regions with predominately Russian-speaking population closer to Russia, made Russian nationalist volunteers to make their way back home, being really disenchanted by the policy of the Kremlin. Igor Srelkov (Girkin), a field commander in self-proclaimed republic of Donetsk, who is very popular among Russian nationalists, announced that he was turning into opposition to the Kremlin.

What is the attitude of the nationalists towards the Kremlin? It is ambivalent.

One the one hand the Russian far right are traditional bearers of anti-Western values based on the Slavophil ideas. And the current conflict between Russia and the West, which has an old tradition, dating back not to the time of the Slavophiles, but even earlier, bring the nationalist closer to the government. Russian nationalists, who are the supporters of the strong power, were really impressed by confrontation with the West and especially with the United States. They warmly approved the returning of Russia to the world politics as a resurrected superpower.

On the other hand Russian nationalists deeply distrust the Kremlin, accusing the government of poorly protecting the interests of the Russians. They believe that the rights of Russians in Russia are infringed and violated in favor of non-Russian ethnic minorities, in particular in favor of Caucasians or the so-called "persons of Caucasian nationality" (lica kavkazskoj nacionalnosti).

The Russian nationalists are also worried about the government's migration policy. The set of their anti-immigration arguments coincides with the arguments of the European far right.

And finally, the nationalists believe that Russia's foreign policy should be much more active and offensive.

The Kremlin, in its turn, has a serious claim to the Russian far right. The government is fearful that the mass campaigning of the nationalists may inspire ethnic unrest in a multinational country.

It is worth stressing, that the Kremlin is wary of any civic and political organization that is not under its complete control. Any autonomy (right or left, it does not matter) is regarded as the risk factor and automatically gets under suspicion.

How popular are the ideas of Russian nationalism in Russia? All independent opinion polls record the significant growth of xenophobia in Russia. For instance, according to the poll, conducted by Levada Polling Center (Levada-Center) in August 2018, more than 63\% of Russians support the idea for introducing the restrictions on the labor migrants. (Levada, 2018).

Paradoxically, despite of the surge of xenophobic sentiments, the popularity of Russian nationalists does not grow in the same pace. A good gauge for this is the popularity of the so-called «Russian marches» - public rally, conducted annually on November 4th, the so-called "National Unity Day". This holiday was introduced in 2005 replacing commemorations of the November 7 - Day of Bolshevik October Revolution in 1917.6

Since their introduction the"Russian marches" gain less popular support, bringing fewer and fewer supporters on the streets. Whereas in 2011 the estimated number of participants in Moscow, according to the Russian Interior Ministry, was from 10000 to 25000 people, in 2013 it was about 10000, in 2014 - about 4000. In 2018 the "Russian March" drew only a few dozen people to the streets of the Russian capital. (Nazhalos Shestvie..., 2018).

This is the evidence of the demise of the far-right organizations in Russia, which now are fully marginalized.

What is the number of Russian nationalist organizations? It is hard to say outright. The official data, provided by Russian Ministry of Justice, in charge of registering political and civic organizations, records not a single registered nationalist organization.

But the unofficial sources provided other data. According to the information, provided by SOVA-Center, for Information and Analysis, by 2012 in Russia were acting more than 60 nationalist organizations. Among them 28 were moderate, 23 - radical and 8 - banned (officially). (Strukova, 2012).

\footnotetext{
${ }^{6}$ Some liberal journalists gave the nickname as "Nazi day", or the day of the nationalist mass demonstration in Moscow and in other Russian cities.
} 
This "clandestine" character of the Russian far right shows, that despite all the hurdles they are not only rather viable, but also have certain potential, which can be realized under certain circumstances. Among them the further deterioration of the economic and social situation (welfare state failure) as a result of the lack of good governance and continuation of conflict between Russia and the West, causing negative aftermaths for the Russian population and stipulating the increase of popular support of the far-right movements.

Exactly all this led to the surge of the popularity of the European far right, whose track the Russian nationalists can reduplicate.

\section{The European and the Russian far Right: Comparative Analysis}

However, for better understanding of perspectives of the far right in Europe and Russia as well as getting insights about the specifics of the far-right movements it is worth making the research based on comparative analysis.

The empirical basis for the research is the data collected within series of research interviews with European and Russian experts as well as open-source information on nationalist and far-right movements in European countries and Russia.

The research sampling encompasses more than 40 selected far-right organizations in Europe (predominately the EU member-states) (Germany - 4, France - 3, Great Britain - 3, the Netherlands - 2, Belgium - 3, Italy - 2, Sweden - 3, Finland - 2, Norway - 2, Denmark - 2, Austria - 2, Greece - 1, Poland - 2, Hungary - 2, Slovakia - 2, Czech Republic - 2, Slovenia -1, Latvia - 1, Lithuania - 1, Estonia -1, Croatia -1) as well as 12 selected far-right organizations in Russia. All sampled organizations are listed in the Table 1.

Table 1. List of far-right organizations in Europe and Russia

\begin{tabular}{|c|c|}
\hline Country & Organization \\
\hline \multirow{3}{*}{ Germany } & - Alternative for Germany (Alternative für Deutschland, AfD) \\
\hline & - National Democratic Party of Germany (Nationaldemokratische Partei Deutschlands, NPD) \\
\hline & - The Blue Party (Die blaue Partei) \\
\hline \multirow{4}{*}{ France } & - National Rally (before National Front) / Marine Blue Gathering/ Rassemblement national/ \\
\hline & Rassemblement bleu Marine, RBM) \\
\hline & - France Arise (Debout la France, DLF) \\
\hline & - Comités Jeanne (Jean-Marie Le Pen) \\
\hline \multirow{3}{*}{ Great Britain } & - The UK Independence Party (UKIP) \\
\hline & - Traditional Unionist Voice (TUV) \\
\hline & - The Brexit Party \\
\hline \multirow{2}{*}{ the Netherlands } & - Party for Freedom (Partij voor de Vrijheid, PVV) \\
\hline & - Forum for Democracy (Forum voor Democratie, FvD) \\
\hline \multirow{3}{*}{ Belgium } & - Flemish Interest (Vlaams Belang, VB) \\
\hline & - National Democratie (Démocratie Nationale) \\
\hline & - Parti communautaire national-européen (PCN) \\
\hline \multirow{3}{*}{ Italy } & $\begin{array}{l}\text { - Northern League/Northern League for the Independence of Padania (Lega Nord, Lega Nord } \\
\text { per l'Indipendenza della Padania }\end{array}$ \\
\hline & - Brothers of Italy (Fratelli d'Italia, FdI) \\
\hline & - Italy for the Italians (Italia agli Italiani, IaI) \\
\hline \multirow{2}{*}{ Austria } & - Freedom Party of Austria (Freiheitliche Partei Österreichs, FPÖ) \\
\hline & - Alliance for the Future of Austria (Bündnis Zukunft Österreich; BZÖ) \\
\hline \multirow{3}{*}{ Sweden } & - Sweden Democrats / Swedish Democrats (Swedish: Sverigedemokraterna, SD) \\
\hline & - Alternative for Sweden (Alternativ för Sverige) \\
\hline & - Citizens' Coalition (Medborgerlig Samling / Borgerlig Framtid) \\
\hline
\end{tabular}

\footnotetext{
${ }^{7}$ Among these open-source information sources are the renowned analytical and research centers as well as think-tanks - Pew Research Center (on European right-wing and populist parties), Carnegie Europe - Carnegie Endowment on International Peace (on European far-right organizations), SOVA Center for Information and Analysis (on Russian nationalist organizations)
} 


\begin{tabular}{|c|c|}
\hline Finland & $\begin{array}{l}\text { - The Finns Party / True Finns (Perussuomalaiset, PS) } \\
\text { - Seven Star Movement (Seitsemän tähden liike) }\end{array}$ \\
\hline Norway & $\begin{array}{l}\text { - Progress Party (Fremskrittspartiet, FrP) } \\
\text { - Norwegian People's Party (Norsk Folkeparti, NFP) }\end{array}$ \\
\hline Denmark & $\begin{array}{l}\text { - Danish People's Party (Dansk Folkeparti, DF) } \\
\text { - People's Movement against the EU (Folkebevægelsen mod EU) }\end{array}$ \\
\hline Greece & 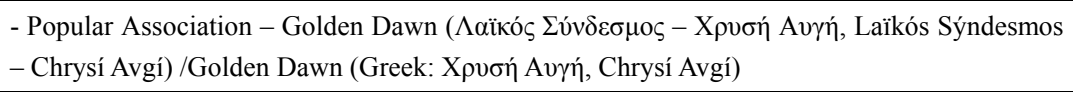 \\
\hline Poland & $\begin{array}{l}\text { - National Rebirth of Poland (Narodowe Odrodzenie Polski, NOP) } \\
\text { - National Movement (Ruch Narodowy, RN) }\end{array}$ \\
\hline Hungary & $\begin{array}{l}\text { - Fidesz - Hungarian Civic Alliance (Fidesz - Magyar Polgári Szövetség) } \\
\text { - Movement for a Better Hungary (Jobbik Magyarországért Mozgalom /Jobbik) }\end{array}$ \\
\hline Slovakia & $\begin{array}{l}\text { - People's Party - Our Slovakia (L'udová strana - Naše Slovensko, LSNS) / Kotleba - People's } \\
\text { Party Our Slovakia (Kotleba - Ludová strana Naše Slovensko) } \\
\text { - Slovak National Party (Slovak: Slovenská národná strana, SNS) }\end{array}$ \\
\hline Czech Republic & $\begin{array}{l}\text { - Freedom and Direct Democracy - Tomio Okamura (Svoboda a prímá demokracie - Tomio } \\
\text { Okamura, SPD) } \\
\text { - National Democracy/No To Brussels - National Democracy (Národní demokracie, ND) }\end{array}$ \\
\hline Croatia & - Croatian Democratic Union (Hrvatska demokratska zajednica, HDZ) \\
\hline Slovenia & - Slovenian National Party (Slovene: Slovenska Nacionalna Stranka, SNS) \\
\hline Latvia & $\begin{array}{l}\text { - National Alliance/ the National Alliance "All For Latvia!" - "For Fatherland and } \\
\text { Freedom/LNNK" (Nacionālā apvienība „Visu Latvijai!” - „Tēvzemei un Brīvībai/LNNK”) }\end{array}$ \\
\hline Lithuania & - National Democratic Party of Lithuania (Lietuvos nacionaldemokratų partija, LNP) \\
\hline Estonia & - Conservative People's Party of Estonia (Eesti Konservatiivne Rahvaerakond, EKRE) \\
\hline Russia & $\begin{array}{l}\text { - Russian All-People`s Union (Rossiyskiy obschenarodnyiy soyuz, ROS) } \\
\text { - "Great Russia” Party (Velikaya Rossiya, VR) } \\
\text { - Russian Imperial Movement (Russkoe Imperskoe Dvijenie, RID) } \\
\text { - Assembly of the Russian Nation (Sobor russkogo naroda, SRN) } \\
\text { - Congress of Russian Communities (Kongress russkih obschin, KRO) } \\
\text { - Russian Liberation Front “Memory” (Russkiy Front Osvobojdeniya "Pamyat”, RFO } \\
\text { "Pamyat”) } \\
\text { - Russian National Unity - Barkashov Guard (OOPD "Russkoe natsionalnoe edinstvo" - } \\
\text { „Gvardiya Barkashova“) } \\
\text { - Russian National Unity - RNE (VOPD "Russkoe natsionalnoe edinstvo" - VOPD RNE) } \\
\text {-Union of Orthodox Banner-Barriers (Soyuz pravoslavnyih horugvenostsev, SPH) } \\
\text { - Union of Russian People (Soyuz russkogo naroda, SRN) } \\
\text { - Movement Against Illegal Migration (Dvijenie protiv nelegalnoy immigratsii, DPNI) } \\
\text { - "Slavic Union” (Slavyanskiy soyuz, SS) }\end{array}$ \\
\hline
\end{tabular}

Although the fully-fledged comparative analysis of the far right in Russia and in Europe turn out to be complicated not only due to the shortage of relevant information, but also the differences in political (democratic vs. non-democratic) and the partisan systems as well as the role of the state and civil society in the process of party-building, the comparison, encompassing organizational, institutional and functional dimensions, is possible by elaboration the special set of criteria, which hereafter can be applied in shaping the comparative model.

From our perspective, the relevant criteria for the comparative analysis of the European and Russian far right are as follows:

- type/character of the organization;

- ideological basis;

- $\quad$ status of organization; 
- institutionalization within the political system;

- forms of action;

- tools of actions;

- popular support.

The "type/character" criterion reflects the predominant form of the organization not only on the basic of proclaimed goals/aims but also of practical activity.

The "ideological basis" criterion shows the ideas and ideologies, determining the activity of the organization.

The "status" criterion reflects the attitude of the authorities (on different levels) towards the far-right organization.

The "institutionalization within political system" criterion gives understanding of the role of the far-right organization within the political system of certain states and their ability to be significant political actors.

The "forms of political action" criterion shows what type of activities of the far-right organization is predominant.

The "tool of political action" criterion anticipates the use of the certain mechanisms for achieving the goals of the organization.

The "popular support" shows the percentage of voters, who are ready to cast their ballot for the far-right organization.

The consideration of the European and Russian far-right movements based on these criteria let to frame the following comparative model, which is shown in the Table 2.

Table 2. The far-right movements in Europe and Russia: comparative model

\begin{tabular}{lll}
\hline \multicolumn{1}{c}{ Criterion } & \multicolumn{1}{c}{ Europe } & \multicolumn{1}{c}{ Russia } \\
\hline Type/Character & Moderate & Moderate/Extremist \\
\hline Ideological basis & Nationalism, Euroscepticism, Xenophobia & Nationalism, Xenophobia \\
\hline Status & Open (registered) & Banned (unregistered) \\
\hline $\begin{array}{l}\text { Institutionalization } \\
\text { within political system }\end{array}$ & Full (well-institutionalized) & $\begin{array}{l}\text { Partial (non-institutionalized } \\
\text { (anomic)) }\end{array}$ \\
\hline Forms of political action & Conventional (parliamentary) & $\begin{array}{l}\text { Conventional/Unconventional } \\
\text { (non-parliamentary) }\end{array}$ \\
\hline Tools of political actions & $\begin{array}{l}\text { Political campaigning (partaking in elections } \\
\text { on different levels), fundraising, mass } \\
\text { campaigning (rallies). }\end{array}$ & $\begin{array}{l}\text { Mass campaigning } \\
\text { rallies) }\end{array}$ \\
\hline Popular support & $\sim 10-14 \% *$ & $\sim 5-8 \% * *$
\end{tabular}

* average-weighted calculation on the results of the general elections in the European countries in 2017-2018.

** own projections

The comparative analysis of the far-right movements by using the empirical data as well as applying the combination of comparative (comparative model), discourse (determination of institutional and functional aspects) and sociological analysis (results of the general elections) eventually enabled to come to the following findings:

- The European and the Russian far right despite huge differences, have much in common. Especially in case of their character, ideological basis as well as tools of action. This can be attributed not only to the essence of nationalist organizations, which have the same "values", but also the globalist effects creation of the global nationalist networking and enhancing cooperation ties;

- The European far right is much better politically institutionalized due to democratic character the political systems (access to the general elections), whereas the Russian counterparts are more anomic, given not only their marginal status (many organizations are officially banned), but also not fully-fledged partisan system, that hampers to create the long-lasting political project (party); 
- The "banned" status of the Russian nationalists opens the door to their transformation into the radical and extremist organizations, what sharply contrasts with the European far right, who are more inclined to use moderate (parliamentary) tools and mechanisms of action;

- The far tight in Europe and in Russia have no "stable" electorate. The popular support is heavily dependent on the dynamics of political and (especially) economic processes. The deterioration in the economic and social sphere leads to the increase of public support (especially within elections). To the contrary, economic improvements determine the lesser support for the far right;

- Currently the far right in Russia has the solid potential, which can be realized under certain circumstances (economic downturn, reemergence of the "besieged fortress" construct as a result of deepening the conflict with the West). But the strengthening of the Russian nationalists and turning them into major political force can stipulate the emergence of the major risks for the Russian state. Among them, the most significant could be the risk of disintegration of the Russian Federation.

\section{Conclusions}

Nowadays we are witnessing the surge of popularity of the far-right ideologies and organizations all over the world. It is relevant for both Europe and Russia, having strong traditions of nationalism. Making the comparison of the European and the Russian far right can help not only to show their differences and similarities, but also to get insights to contemporary development of political systems and political cultures.

The proposed in the article comparative analysis of the far right in Europe and Russia revealed, that despite remarkable differences, given the historical as well as political background the far-right movements have much in common. This can be attributed not only to the ideological aspects (nationalism and xenophobia as the core ideology), but also to the organizational and functional aspects.

The latter are strongly connected to the forms and tools of political activity, applied by far-right movements (the most preferable is still mass campaigning). But given the better institutionalized character as political actors as well as developed democratic institutions in Europe the European far right tend to use political campaigning, envisaging partaking in the elections on the different levels (supranational, national, regional, local) as the major mechanism of the political activity.

This trend, which is stipulated by surging public support of the far-right movements in many European countries given the bunch of factors - lack of good governance, social and economic problems, turns out to be the sustainable, igniting the process of demarginalization of the European far right. They are still widely regarded as non-traditional political forces. However, already not as political midgets.

Moreover, the entry of the many far-right organizations to the governments, acting on the different levels, in many European countries opened the way to their institutionalization and self-establishment as political forces, which must be taken into account anyway.

The Russian far right could not boast the same results as their European counterparts. This can be partly attributed to the repressive policy, applied by the Russian authorities, partly by the fact that the extreme right do not have enough capacity to articulate growing social, economic and ethnic discontent in Russia.

But anyway given the current trends in the political and economic sphere in Russia the far-right movements have certain potential and incentives for building up themselves as political actors becoming one of the major beneficiaries of political development in Russia in the medium- and long-term perspective.

Nominally, this can equate them with the European counterparts. However, whether it will lead to ultimate demarginalization of the far-right movements in Russia and their conversion into conventional political force is still an open question.

\section{References}

Albertazzi, D., \& McDonnell, D. (2008). Introduction: The sceptre and the spectre. In Albertazzi, D., \& McDonnell, D. (Eds.), Twenty-first century populism (pp. 1-11). New York: Palgrave Macmillan.

Art, D. (2011). Inside the Radical Right: The Development of Anti-immigrant Parties in Western Europe. Cambridge: Cambridge University Press.

Betz, H.-G. (1994). Radical right-wing populism in Western Europe. Basingstoke: Macmillan.

Bjørgo, T. (1997). Racist and Right-WingViolence in Scandinavia: Patterns, Perpetrators and Responses. Oslo: Tano Aschehoug Hate Movement. Berkeley: University of California Press.

Brattberg, E., \& Meyerweissflog, V. (2017). 2017's Verdict on European Populism. Carnegie Endowment for 
International

Peace.

20.12.2017.

Retrieved

from

https://carnegieendowment.org/2017/12/20/2017-s-verdict-on-european-populism-pub-75081

Carter, E. (2005). The extreme right in Western Europe: Success or failure? Manchester: Manchester University Press.

Charalambous, G. (2015) The European Far Right: Historical and Contemporary Perspectives. PRIO Cyprus Centre /Friedrich-Ebert- Stiftung. Report 2/2015.

Delcic, M. (2017). In German Elections Neo-Nazi Fringe rises - and here's why? Newsweek. 25.09.2017. Retrieved from https://www.newsweek.com/extremism-europe-rise-fringe-angela-merkel-670657

Della Porta, D. (1995). Social Movements, Political Violence and the State. Cambridge: Cambridge University Press.

Doroshenko, L. (2018). Far-Right Parties in the European Union and Media Populism: A Comparative Analysis of 10 Countries during European Parliament Elections. International Journal of Communication, 12, 3186 3206.

Dunlop, J. B. (1985). The new Russian nationalism.

European Elections 2019: what will the new Parliament's composition be? European Issues No 491. Foundation Robert Shuman. Retrieved from https://www.robert-schuman.eu/en/european-issues/0491-european-elections-2019-what-will-the-new-parli ament-s-composition-be

Geert Wilders' Speech In Berlin On 2 October 2010. International Civil Liberties Alliance. Retrieved from http://www.libertiesalliance.org/2010/10/02/geert-wilders-speech-in-berlin-on-2-october-2010/

Georgiadoua, V., Rorib, L., \& Roumanias, C. (2018) Mapping the European far right in the 21st century: A meso-level analysis. Electoral Studies, 54, 103-115.

Heinisch, R. (2008). Austria: The structure and agency of Austrian populism. In Albertazzi, D., \& McDonnell, D. (Eds.), Twenty-first century populism (pp. 67-83). New York: Palgrave Macmillan.

Heitmeyer, W. (2002). Rechtsextremistische Gewalt. In Heitmeyer, W., \& Hagan, J. (Eds.), Internationales Handbuch der Gewaltforschung (pp. 501-546). Wiesbaden Westdeutscher Verlag.

Ignazi, P. (1992). The silent counter-revolution: Hypotheses on the emergence of radical right-wing parties in Europe. European Journal of Political Research, 22(1), 3-34.

Ilyin, I. A. (2007). O russkom nationalizme.

Ivarsflaten, E. (2008). What unites right-wing populists in Western Europe? Comparative Political Studies, 41(1), $3-23$.

James, P. (2006). Globalism, Nationalism, Tribalism: Bringing Theory Back in. Books. Paul James.

Kir'ianov, U. (2001). Pravye partii. 1911-1917.

Kinyakin, A., Kazarinova, D., \& De Martino, M. (2017) Transformation of social and political values in the EU. Round-table discussion paper. RUDN Journal of Political Science, 19 (2), 183-214.

Kitschelt, H. (1997). The radical right in Western Europe. Ann Arbor, MI: University of Michigan Press.

Kozhevnikova, G. (2009). Radical Nationalism in Russia in 2008, and Efforts to Counteract It.

Laquer, W. (1993). Black Hundred. The Rise of the Extreme Right in Russia. HarperCollins Publishers (first published June 1st 1993)

Laruelle, M. (Ed.). (2018). Entangled Far Rights: A Russian-European Intellectual Romance in the Twentieth Century (Russian and East European Studies) Paperback.

Leoussi, A. S. (Ed.). (1991). The Encyclopaedia of Nationalism. Taylor \& Francis. Published. New Brunswick, N.J.

Llobera, J. R. (1999). Recent theories of nationalism. Barcelona.

Löfven labels Sweden Democrats "Neo-fascists". Radio Sweden. 06.12.2014. Retrieved from https://sverigesradio.se/sida/artikel.aspx?programid $=2054 \&$ artikel $=6038795$

Lubbers, M., \& Scheepers, P. (2007). Euro-scepticism and extreme voting patterns in Europe: Social cleavages and socio-political attitudes determining voting for the far left, the far right, and non voting. In G. Loosveldt, M. Swyngedouw, \& B. Cambre' (Eds.), Measuring meaningful data in social research (pp. 71-92). Leuven: Acco. 
Minkenberg, M. (2000). The renewal of the radical right: Between modernity and anti-modernity. Government and Opposition, 35(2), 170-188.

Mitrohin, N. (2003). Ot "Pamyaty" $k$ skinhedam Luzkova. Ideologia russkogo nationalizma // Neprikosnoveny zapas.

Monitoring of xenophobic sentiments (Monitoring Ksenofobskih Nastroenij), Jule 2018, Levada Polling Center. Retrieved from https://www.levada.ru/2018/08/27/monitoring-ksenofobskih-nastroenij/

Motyl, A. (Ed.). (2000). Encyclopedia of Nationalism (1st ed.). Publisher: Academic Press.

Mudde C. (2005). Racist extremism in Central and Eastern Europe. East European Politics \& Societies, 19(2), $161-184$.

Mudde, C. (2007). Populist radical right parties in Europe. Cambridge: Cambridge University Press.

Mudde, C. (2016). On Extremism and Democracy in Europe. Abingdon: Routledge.

Nachalos Shestvie po ulice Pererva. Press-Sluzhba GU MVD Rrossii po g. Moskve. Retrieved from https://77.мвд.pф/news/item/8864769/?year=2018\&month=11\&day=4

Norris, P. (2005). Radical right: Voters and parties in the electoral market. New York: Cambridge University Press.

Rogger, H. (1964). Was There a Russian Fascism? The Union of Russian People. The Journal of Modern History, 36(4), 398-415.

Shekhovtsov, A. (2017). Russia and the Western Far Right: Tango Noir (1st ed.). Publisher: Routledg.

Shenfield, S. (2001). Russian Fascism: Traditions, Tendencies, Movements. New York: M. E. Sharpe.

Simmons, K., Silver, L., Johnson, C., Taylor, K., \& Wike, R. (2018). In Western Europe, Populist Parties Tap Anti-Establishment Frustration but Have Little Appeal Across Ideological Divide. Pew Research Center, July, 2018.

Retrieved

from

https://www.pewglobal.org/2018/07/12/in-western-europe-populist-parties-tap-anti-establishment-frustratio n-but-have-little-appeal-across-ideological-divide/

Solovey, T. D., \& Solovey, V. D. (2009). Nesostojavshayasia revolutsia. Istoricheskie smisli pusskogo nationalisma.

Stepanov, S. A. (2013). Chernaya sotnia v Rossii. 3-d ed.

Stepanov, S. A. (2018). Chernosotentsy v period Fevralskoy revolutsii $1917 \mathrm{~g}$.

Strukova, E. (2012). Partii Russkih Nacionalisto: Registraciya v Minyuste. SOVA-Center for Information and Analysis. Retrieved from https:/www.sova-center.ru/racism-xenophobia/publications/2012/05/d24385/

Toscano, E. (Ed.). (2019) Researching Far-Right Movements: Ethics, Methodologies, and Qualitative Inquiries. Social Movements in the 21st Century: New Paradigms.

Verkhovsky, A. M., \& Kozevnikov, G. V. (2009). Radicalniy russkiy nationalism: struktura, idei, litsa.

Wagemann, C. (2005). Right-wing extremism in Germany. In Della Porta, D., \& Wagemann, C. (Eds.), Patterns of Radicalization in Political Activism: Research Design (pp. 23-50). Florence: Veto Project Report.

Yudina, N., \& Alperovich, V. (2015). The Ultra-Right Movement under Pressure: Xenophobia and Radical Nationalism in Russia, and Efforts to Counteract Them. Retrieved from http://www.sova-center.ru/en/xenophobia/reports-analyses/2016/04/d34247/

Zaderey, V. A. (2012). Kritichesky analiz strategii i tktiki Souza Russkogo naroda.

Zimmermann, E. (2003). Right-wing extremism and xenophobia in Germany: Escalation, exaggeration, or what? In Merkl, P. L., \& Weinberg, L. (Eds.), RightWing Extremism in the Twenty-First Century (pp. 220-250). London and Portland, OR: Frank Cass.

\section{Copyrights}

Copyright for this article is retained by the author(s), with first publication rights granted to the journal.

This is an open-access article distributed under the terms and conditions of the Creative Commons Attribution license (http://creativecommons.org/licenses/by/4.0/). 